\title{
Old Saxon unmet, Genesis B 313b ungemet, and unmetrical scribal forms in germanic alliterative verse
}

\section{Nelson Goering}

To cite this article: Nelson Goering (2020): Old Saxon unmet, Genesis B 313b ungemet, and unmetrical scribal forms in germanic alliterative verse, Studia Neophilologica, DOI: 10.1080/00393274.2020.1851296

To link to this article: https://doi.org/10.1080/00393274.2020.1851296

曲 Published online: 04 Dec 2020.

Submit your article to this journal $₫$

Q View related articles $\longleftarrow$

View Crossmark data $\asymp$ 


\section{Old Saxon unmet, Genesis B 313b ungemet, and unmetrical scribal forms in germanic alliterative verse}

\section{Nelson Goering}

Faculty of Linguistics, Philology and Phonetics, University of Oxford, Oxford, UK

\section{ABSTRACT}

The adverb ungemete, unigmetes in Beowulf and elsewhere in Old English verse creates significant metrical problems. I revive and expand the proposal of Fulk (1992) to read this as *unmet. This restoration receives support from metrics and from the comparison with Old Saxon unmet of the same meaning, and the alteration to ungemet(e), etc., in the manuscripts is easily explained by Old English scribal practices.

\section{ARTICLE HISTORY}

Received 10 July 2020

Accepted 9 November 2020

\section{KEYWORDS}

Beowulf; Old English; Old

Saxon; Emendation;

Alliterative verse

\section{The problem}

The words unigmetes and ungemete 'exceedingly, immeasurably' present a well-known metrical problem at their four occurrences in Beowulf ${ }^{1}$

(1)

(a) gamela Scylding. Ġēat unigmetes wēl 'old Scylding. The Geat exceedingly greatly ...' (Beo 1792)

(b) wǣfre ond wælfūs, wyrd unġemete nēah 'agitated and eager for battle, fate exceedingly close' (Beo 2420)

(c) pēoden mǣrne, peg்n ungemete til 'famous king, thane exceedingly good' (Beo 2721)

(d) dōgorg̉erīmes, dēað unġemete nēah 'of his count of days, death exceedingly close' (Beo 2728)

The essential problem is that the underlined words result in unmetrical patterns. The un- is most likely stressed (see below), leaving either -igmetes or -gemete to sit in what would most typically be a monosyllabic, fully unstressed dip of a type D4 (Db) verse. ${ }^{2}$ For a more routine verse of this type, compare:

\footnotetext{
CONTACT Nelson Goering nelson.goering@ling-phil.ox.ac.uk Somerville College, Oxford, UK

${ }^{1}$ Cited from Fulk, Bjork \& Niles (2009).

${ }^{2}$ I use Sievers' usual labels (and light revisions of it, including 'Da' for types D1-3, and 'Db' for type D4), though this is a matter of convenience in labelling, and does not represent a strong commitment to any specific theoretical underpinning of Old English metre. All the relevant metrical observations hold just as well under the word-foot theory of metre (Russom 1987). 
(2) bona swīðe nēah

'the slayer exceedingly close' (Beo 1744b)

Beyond Beowulf, forms of this adverb appear some 30 times in the corpus of poetry, ${ }^{3}$ nearly always as the first word in an off-verse followed by a heavy trochee:

(3) is heora ealdordōm ungemete swīðe

'their lordship is exceedingly great' (PPs 138.15)

This and the many similar verses, mostly from the Metrical Psalms, clearly show that the un- indeed bears the main stress, since the alliteration is always vocalic. These verses would seem to scan as type A, which is more tolerant of expanded dips between the first two lifts. Nonetheless, one would normally assume some degree of secondary stress on -me-, which would result in an unmetrical pattern.

\section{Previous explanations}

The four examples from Beowulf have attracted attention throughout the entire history of modern Old English metrical studies. Sievers (1885: 260) scans these as type D4 (Db), assuming that all the syllables after un- are unstressed: SSwwws. ${ }^{4}$ In Sievers (1893: 130), he proposes extending the form of 1792, beginning with unig-, to all the instances in Beowulf, in order to allow resolution, resulting in the dip only containing two syllables in each case. This solution is unacceptable for two major reasons: resolution of unig- after a stressed monosyllable would violate Kaluza's law, and unigmet- is a late variation of ungemet- in the history of Old English (Fulk, Bjork \& Niles 2009: cxli), and is more likely to be a scribal replacement for the latter rather than the reverse. The linguistic basis for assuming such a run of unstressed syllables without giving prominence to -me- is not something Sievers attempts to justify, and this remains a dubious proposal. Momma (1990) and Suzuki (1996: 21-22) would also take this as a variety of type D.

An alternative view, proposed by Pope (1966: 330-331), holds that in Beowulf the un- is, in fact, unstressed, and -mete forms a resolved half-lift. This is also the conclusion arrived at by Russom (1987: 120-121), and it is accepted 'with some hesitation' by Kendall (1981: 48), who is followed in turn by Hutcheson (1995: 265). Under this scansion, the metrical pattern of the four verses in question would then be Swwš ${ }^{\mathrm{w}} \mathrm{S}^{5}$ an 'E2' type otherwise not attested in Beowulf at all. Furthermore, in all but one of its non-Beowulfian occurrences, un- is clearly stressed and alliterating (the exception is Met 11.59 , which has the same rhythm and same problems as the examples from Beowulf).

\footnotetext{
${ }^{3}$ Statements about attestation in Old English poetry are based on Bessinger (1978), checked against the Dictionary of Old English Corpus. Citations are from Krapp \& Dobbie (1953), unless specified otherwise, and short titles follow Mitchell, Ball \& Cameron (1975). With ungemet (4x): GenB 313 (discussed below), PPs 56.5, 61.2, Met 11.59. With ungemete (17x, in addition to the $3 x$ in Beowulf): PPs 72.5, 98.1, 108.2, 108.3, 108.27, 115.1, 115.2, 118.50, 118.58, 118.70, 118.150, 118.161, 138.15, 141.6, 141.7, 142.3, 143.17. With ungemetum (5x): PPs 118.67, 118.107, 142.1, MRune 29, JDay II 194. With ungemetun (1x): MRune 8. With unigmet (2x; cf. the 1 instance of unigmetes in Beowulf): Met 7.33, 10.9.

${ }^{4} S$ stands for a stressed syllable, $s$ for a secondarily stressed syllable, and $w$ for a weak or unstressed syllable. See Stockwell (1996) and Goering (2020: 141, fn. 5) for details of metrical notations for Old English.

${ }^{5}$ The $\breve{s}^{w}$ marks a short syllable (indicated by the breve) followed by an unstressed syllable which has resolved with it, so that this is equivalent to SwwsS.
} 
Rather than choosing which element to stress, un- or -me-, Bliss (1962: 77-78) argues that the entire adverb is unstressed, so that the scansion of the Beowulf verses would be SwwwwS. This is linguistically unlikely (see in particular Russom 1987: 120-121) and would still result in an unparalleled metrical pattern (Pascual 2013: 55-56).

A more recent proposal comes from Yakovlev (2008: 59, fn. 26), ${ }^{6}$ who very tentatively suggests a double application of Cable (1991: 13-16) prefix exemption to construe both un- and ge- as extrametrical, resulting in scansions like wyrd (unge)mete néah, where the brackets signal material ignored by the prefix licence. ${ }^{7}$ Even if one in general accepts Cable's argument that prefixes may be disregarded in scansion, this would be a highly unusual instantiation of the licence, applying to two separate prefixes to entirely eliminate the second position of a verse. The application of the prefix licence under any circumstances to un- is furthermore doubtful, for much the same reasons as Pope's decision to take un- as unstressed.

All of these attempts to stress or destress various parts of the adverb involve linguistic difficulties, and even so none result in acceptable metrical patterns. Since the initial problem is essentially metrical, none of these can be considered an adequate solution, and all of these approaches may be safely set aside.

\section{A solution}

One further suggestion is proposed in a footnote by Fulk (1992: 70, fn. 14):

$[\mathrm{N}]$ early all the thirty-seven instances [of ungemet- in verse $]^{8}$ require unmet-, instead, and none would be rendered unmetrical by the substitution. Unmet- as a simplex (cf. O[Id] Sax[on] unmet, O[ld] H[igh] G[erman] unmez, ungamez) is attested twice in Bede's Ecclesiastical History, and even once in verse, at Instructions for Christians 136b, if these are not simply variant spellings of unmēt.

That is, Fulk argues that Old English poets generally intended disyllabic unmet here, and that the longer ungemete (and similar) of the manuscripts is an artefact of scribal norms that does not reflect the content of the poems in question.

This proposal has, as far as I can see, been taken up by no metricists or editors since, not even Fulk, Bjork \& Niles (2009), which Fulk helped edit. The form *unmet could not have been printed as such, according to the editorial philosophy of that edition, where metrically motivated readings are signalled primarily through underdotting - in this case, these words could have been given as ung̣emetẹ, unịgmetẹ̦. But no such marking is employed in these instances, and even in the commentary the reading *unmet is not explicitly included in the range of possibilities (Fulk, Bjork \& Niles 2009: 216-217, s.v. $1792^{\mathrm{b}}$. unigmetes; a citation leads to Fulk's footnote, quoted above, but the possible reading *unmet is not directly suggested). It is, nonetheless, a solution with much to recommend it: it is linguistically plausible, results in excellent metre, and fits into a well-

\footnotetext{
${ }^{6}$ I thank the anonymous reviewer for drawing Yakovlev's discussion to my attention.

${ }^{7}$ Yakovlev gives the scansion as SppSrs, with $S$ standing for a stressed syllable, $s$ for a secondary stress, $p$ for an extrametrical prefix, and $r$ for a resolved syllable. This must be a mistake, since this would result in the scansion of, effectively, SSs, with only three metrical positions - a type whose existence is ruled out by Yakovlev's framework. He presumably intended SppSxs instead, with suspension of resolution. However, since suspension is not expected after a fully unstressed syllable, this difficulty with resolution is a further reason for doubting this suggestion.

${ }^{8}$ This tally includes adjectives as well as adverbs.
} 
founded view of the scribal habits of late Old English copyists. The following sections examine each of these points in turn.

\section{Old Saxon unmet}

Old Saxon represents the most closely related poetic tradition to Old English, with its two major poetic works - Heliand and the shorter surviving fragments of Genesis - very similar in lexis and style to their Insular counterparts. In this corpus, unmet occurs three times ${ }^{9}$

(a) ōður mag man olbundeon, thōh hē sī unmet grōt 'more easily can one [push] a camel, though it be exceedingly large ...' (Hel 3299)

(b) ar biðð-uuerco, huīlon unmet hēt '[we suffered many] difficult labours, while [the sun shone] exceedingly hot' (Hel 3437)

(c) fulliad mid iro fer ${ }^{\mathrm{a}} \mathrm{hu}$; ferid $\underline{\text { unmet }}^{10}$ grōt 'come to an end with their life; [hateful hunger] comes, exceedingly great' (Hel 4329)

The word is also found twice in the Hildebrandslied, a poetic text of unclear dialect affiliation (some structural elements appear to be Saxonisms, but other features are at odds with this; the surface form is extremely mixed), but certainly an important representative of early West Germanic poetic tradition ${ }^{11}$

(a) her was Ōtachre ummet tirri

'he was exceedingly angry with Odoacer' (Hild 25)

(b) du bist dir altēr Hūn, ummet spāhēr

'you old Hun, you are exceedingly cunning' (Hild 39)

In (5a), the MS has ummettirri, which may be read in various ways. Braune (1994), following Grein (1858: 26), simply puts a word division between the two $t$ 's, reading the exact equivalent of Old Saxon unmet, though the word tirri is unusual and must be either conjecturally explained or emended. Others, going back to Lachmann (1835: 142-143), have preferred to place the word boundary after the $t^{\prime} s$, ummett irri, or, following Lühr (1982), understand ummett $<i>$ irri, with one of the two sequential $i$ 's being elided (scansion would suggest this elision is metrical, not just scribal). This would replace the awkward hapax tirri with the well-attested adjective irri 'angry' (cognate with Old

\footnotetext{
${ }^{9}$ Cited, with some adaptation, from Behaghel \& Taeger (1996), with reference to Sievers (1878) and Tiefenbach (2010).

${ }^{10}$ Thus in MS C; M has unm\&, using the ampersand as a shorthand for the letter sequence et at the end of a line: https:// daten.digitale-sammlungen.de/0002/bsb00026305/images/index.html?id=00026305\&groesser=\&fip=193.174.98. $30 \&$ no $=\&$ seite $=126$.

${ }^{11}$ Cited from Braune (1994: 84-85), with the addition of vowel length marks. (5a) is line 24 in Lühr (1982: 2-4), while (5b) is line 35. Fulk, Bjork \& Niles (2009: 339-341) also edit the poem, in which (5b) is line 37.
} 
English yrre), at little palaeographic cost - but it would make for an unusual case of double alliteration in the off-verse. The correct reading is not easy to determine. But even if the reading ummett $<i>$, less like its Old Saxon counterparts, is accepted, the important point for the immediate purpose is the lack of any gi- prefix. In both instances, the words show a trivial assimilation of $\mathrm{nm}$ to $\mathrm{mm}$.

The prose corpus of Old Saxon is rather meagre, but it does include one instance of ungimet, with the gi- element (Merseburger Glosses 71, 5). This would seem to parallel the situation I propose for Old English: *unmet in the poetic register, and longer, prefixed forms ungimet, ungemete(-) more typical of prose. ${ }^{12}$

\section{Scansion}

If we introduce *unmet into Old English poetry, parallel to Old Saxon, the verses in (1) would read as:
(a) gamela Scylding. Gēat unmet wēl 'old Scylding. The Geat exceedingly greatly ...' (Beo 1792)
(b) wǣre ond wælfūs, wyrd unmet nēah 'agitated and eager for battle, fate exceedingly close' (Beo 2420)
(c) pēoden mǣrne, peg̀n unmet til 'famous king, thane exceedingly good' (Beo 2721)
(d) dōgorg̈erīmes, dēað unmet nēah 'of his count of days, death exceedingly close' (Beo 2728)

Met 11.59 would also scan comparably. Taking the un- as stressed (as it must be elsewhere), the second element of this grammaticalized adverb is open to significant demotion to be treated as an unstressed element, being both word final and immediately subordinated to the preceding primary stress (avoidance of stress clash). These verses would all scan identically to (2), and indeed to (4c), probably showing the D4 (Db) rhythm SSws, though scansion as type E (SswS) is also possible if such a distinction is even to be maintained in off-verses (Cable 1974: 75-79, Suzuki 1996: 113-121). Either way, such verses are a well-established part of the Old English metrical repertoire (see further Suzuki 2004: 276 and Hofmann 1991: 194, 269 for the comparable scansion of $4 \mathrm{c}$ ).

Other verses are also metrically improved. (3) would be read as a simple type A verse, the most basic rhythm in Old English poetry:

\footnotetext{
${ }^{12} \mathrm{~A}$ full treatment of the Old High German material is beyond the scope of this discussion. It is worth noting, however, that we do find both the plain adverb unmez, as well as extended adverbial forms such as ungimezzon. In the early Abrogans, we find both an adverbial unmez and adjectival ungamezzi alongside one another. There was likely a good deal of analogical influence between adverbial and adjectival forms in West Germanic generally, and it does not seem implausible to suppose the ga-/gi-/ge-forms on the whole to be typologically younger. The suffixed adverbial forms such as extended ungemete and possible ummett $<i>-$ are very likely younger elaborations, showing various productive ways of more explicitly märking the form as an adverb than the bare unmet did.
} 
(7) is heora ealdordōm unmet swīðe

'their lordship is exceedingly great' (PPs 138.15)

And similarly for most of the remaining instances of this adverb in the corpus. ${ }^{13}$

There are two verses with surface forms ungemete in which the substitution of *unmet would result in poorer metre ${ }^{14}$

(8)

(a) pæt of ungiemete æ̈lćes ðinges

'that from the immoderation of every thing' (Met 25.38)

(b) æpelinges sīo. Hīo mid ungemete

lissum lufode...

'the journey of the noble one. She loved [him] with immoderation, tenderly' (Met

26.62-63)

In neither of these is ungemete an adverb (and these verses are accordingly not listed in the catalogue in note 2 above). Rather, ungemete is in each case an abstract noun in the dative singular (cf. Old High German unmez 'excess', modern German Unmaß). It is possible that these verses should also have the -ge- removed to avoid violating the constraint against compounds of the shape Sw $\breve{s}^{w}$ (Terasawa 1994), but the nominal case ending must be retained. With *unmete, these verses would each scan as unremarkable examples of type $C$.

\section{Scribal replacements of *unmet}

Even if we assume the form * ${ }^{*}$ unmet is linguistically correct in Old English poems, questions remain about how and why ungemete ${ }^{15}$ came to be written in the surviving manuscripts. The simplest assumption is that the text as originally composed contained the form *unmet, which stood as such in the earliest manuscripts, and that this was altered by scribes in the course of transmission. ${ }^{16}$ The motivation would simply be that they

\footnotetext{
${ }^{13}$ Most examples are in the off-verse; one, at PPs 118.61, is in the on-verse (with scribal geneahhie to be read as a variant of geneahhe).

${ }^{14}$ Strictly speaking, with *unmet (8a) could scan as a variety of $A 3$, but it would be an unusual example of the type.

${ }^{15}$ And similar. From here on out, unless specified otherwise, I will use ungemete as a stand-in for all expanded variants, including unigmetes, ungemetum, etc.

${ }^{16} \mathrm{~A}$ more complex possibility is that these texts always showed forms comparable to ungemete in their written traditions. More complex, because it requires an early and enduring mismatch between the scribal forms and poetic pronunciation, so that over the course of several centuries scribes consistently wrote tetrasyllabic ungemete (or ungimetæ, etc.) alongside a pronunciation as disyllabic unmet. It also supposes that longer forms such as ungemete had both come into existence and become the standard in writing already in the early Old English period. In both respects, linguistic and scribal, this would appear to rest largely on projecting the situation of later West Saxon onto much earlier Anglian of the seventh or earlier eighth centuries for Beowulf, and I cannot see any supporting evidence to justify this. The Metrical Psalms are generally regarded as a later composition, but even so it is simpler to assume that the poet wrote the form that fits better with the metre, and to attribute the late textual form to the late scribe who was not interested in the finer metrical details of syllable counts (the manuscript dates to the middle of the eleventh century). Only the Metres of Boethius were likely composed in West Saxon (perhaps even by King Alfred, though the attribution remains controversial), in a context where we can be reasonably sure that ungemete was the ordinary form in prose (and presumably speech). Perhaps here there would be more scope for a mismatch from the beginning between poetic and written form in the three occurrences of ungemet, unigmet that occur in this poem - though it is worth noting that
} 
(correctly) equated *unmet in their exemplar with the common form ungemete of later written Old English.

The Old Saxon material may show a similar process of scribal updating. As is well known, Genesis B (i.e. lines 235-851 of Genesis in MS Junius 11) is translated from Old Saxon into Old English, and fragments of the original Genesis, including a short overlapping passage found in both languages, have been discovered. To judge by the usage in Heliand, we would expect any instances of our adverb occurring in the Old Saxon Genesis to be *unmet. While this adverb does not occur in the surviving Old Saxon passages, a relevant form is found in the Old English translation: ${ }^{17}$

(9) pǣr hæbbað hēo on ǣfyn unġemet lange

'There they have in the evening, exceedingly long ...' (GenB 313)

This word is at best metrically uncomfortable (as already discussed), and both metre and the Old Saxon evidence converge to suggest that the original of $313 \mathrm{~b}$ was ${ }^{*}$ unmet lango, both in linguistic form (as suggested by the metre) and in actual orthographic form (as suggested by the evidence of Heliand). If so, then a scribe has, at some unknown point along in the course of transmission and translation, converted this *unmet either directly to Old English ungemet (if this happened during or after translation) or via Old Saxon *ungimet, which was then further altered to ungemet. If the former is what took place, the occurrence of ungemet rather than ungemete may be due to the scribe employing a slightly more conservative, less expanded form: ungemet is a less common form, but may be found alongside ungemete in both Early and Late West Saxon, and is the preferred form in some texts, such as Bald's Leechbook II. If the latter, then a (Saxon) scribe has already 'modernized' the poetic *unmet to the more prosaic *ungimet before translation, which was only further altered in West Saxon to the point of accomodating the ge- prefix to the usual later Old English form.

This sort of 'modernization', particularly on the Old English side, is in keeping with the typical behaviour of scribes copying texts not already written in their quasi-standard orthographic system. ${ }^{18}$ Neidorf (2017: 103), in his systematic review of this issue, summarises the usual approach:

When the scribes correctly identified the word before them, they altered the superficial characteristics of the antecedent reading in order to commit the word's standard Late West Saxon form to parchment. When the scribes erred in their identification, they would transmit a word of similar appearance that was intelligible and genuine, but manifestly erroneous in the present context.

the sequence -i $\dot{g}$ - is unlikely to be original, and is presumably either altered from - $\dot{g}$ - in ungemet, or introduced during an expansion of *unmet. Either way, a minimum of scribal alteration seems to be inescapable, and the motivation for rigorously back-projecting the habits of later scribes onto earlier manuscripts still strikes me as rather weak. However this may be, these speculations concern the written forms this adverb might have taken in poetic manuscripts in different periods and contexts, while I am primarily concerned with establishing the likely poetic and linguistic values used by poets in composition.

${ }^{17}$ Cited from Doane (1991), with slight adaptation.

${ }^{18}$ It is worth noting that while we call 'Old Saxon' a different language, it is hardly clear that a scribe copying Genesis $B$ would have felt this to be exceptionally more distant or difficult than an early manuscript in early Anglian Old English. The process of 'modernizing' an 'Old English' poem such as Cædmon's Hymn or the Leiden Riddle/Riddle 35 into Late West Saxon can hardly have fundamentally different from the process of 'translating' Genesis B from 'Old Saxon'. 
The first option - successful identification of early Old English *unmet with Late West Saxon ungemete - is, I propose, what took place with *unmet, at least in Beowulf, and possibly at all the occurrences listed in note 2 .

Such a scenario assumes that *unmet existed, at least in the poetic language, earlier in Old English. This is supported chiefly by the Continental cognates discussed above, since a bare form *unmet is not found as such in the Old English corpus, prose or poetry. None of the forms cited by Fulk are adverbial, nor are they formally plain *unmet. However, they, along with four instances of forms of unmetlic (adjectival in the prose Life of St. Guthlac and Orosius; adverbial in the Letter of Alexander and the Liber Scintillarum), do attest to the presence in Old English of a base unmet-, not extended with -ge-. It is worth noting that no relevant forms are found in the very earliest texts at all, and the absence of a bare *unmet does not speak strongly against the reconstruction of such a form based on metrical evidence, aided by the analogue of Continental West Germanic.

What is required for this hypothesis is that, as perhaps also happened in Old Saxon, the prefixed variants were productive, and became the norm in later Old English (and strongly so in West Saxon). In a fairly routine type of further characterisation, the form would also be extended by more overt adverbial suffixes: most frequently -e but also -es, -um/-un, and - lic $^{19}$ (this did not take place in recorded Old Saxon, and is less thoroughgoing in Old English). The prefix itself became entrenched enough to be worn down to simple -i- (a general form in Middle English; cf. the extremely frequent unimete in Lazamon's Brut), early enough for Scribe A of the Beowulf manuscript to write unigmetes (ig is usually graphic for $i$ in late Old English). The more conservative Scribe B writes the more etymological ungemete, either because that was the variant in their speech (this scribe is widely held to be older than A, on the basis of their handwriting style), or because they held more strictly to 'standard' spelling conventions and so wrote what had been a geprefix as such.

When coming across the to-them archaic form *unmet, these scribes did what they usually did: converted the lexeme into a familiar modern form, copying an original line such as *uyrd unmet neh (or similar) to pyrd ungemete neah. In the process, the metre was disturbed, but this was not disturbing to the typical late scribe, who had other priorities.

\section{Conclusion}

Fulk's suggestion to restore unigmetes and ungemete in Beowulf to *unmet solves a minor but persistent metrical issue in the poem. With instances of this sort, where a single lexeme repeatedly seems to behave metrically oddly, there should be a strong suspicion that a linguistic story of some sort lies behind the attested forms. In this case, the assumption that poetic Old English retained a disyllabic adverb *unmet 'exceedingly', is linguistically plausible, and well supported by cognates in Old Saxon (including in the closely related poetic tradition of the Heliand) and Old High German. The assumptions that this form was recharacterized to ungemete (and similar), and that scribes, especially Late West Saxon scribes, would have used such a now-ordinary form in place of older *unmet without regard for metre, are both also plausible, in keeping with expected developments in the language and in scribal culture.

\footnotetext{
${ }^{19}$ Also used as an adjectival formative.
} 
This reading has not generally been taken up by editors or metricists. That the reading *unmet has not been printed directly in any major edition is not surprising, since Old English editorial practice tends to be conservative, but there are tools such as underdotting which have been employed to mark the secondary nature of comparable young linguistic forms. More significantly, this possibility is generally not considered in the various metrical and textual discussions of these verses (including commentaries in editions) that have appeared since Fulk (1992).

The lack of integration of Old Saxon material into Old English studies may be a contributing factor to the poor reception of this restoration. Although Heliand and Genesis should, by any reasonable metric, form a central part in the study of Old English verse, Old Saxon is generally treated as something distinct, at best an optional supplement rather than as a sizeable corpus shedding essential light on the language and poetics of the Ingvaeonic dialects of northwestern Europe. This has, perhaps, led the ready example of unmet from that corpus to be too readily left out of consideration as a solution for the problematic ungemete, etc.

Whatever the reasons for the lack of attention given to * unmet, I do not think that there is any good reason to defend the manuscript readings for this adverb. Restoring to *unmet is metrically far preferable, linguistically plausible, and easily explained in terms of scribal behaviour.

\section{Acknolwedgements}

I would like to thank R. D. Fulk and Rafael Pascual for reading over a draft of this paper, and the anonymous reviewer for many helpful and insightful comments. I am also grateful to the British Academy for their support of the research project Old Norse Influence on Middle English Prosody, of which this was an outgrowth.

\section{Disclosure statement}

No potential conflict of interest was reported by the author.

\section{Funding}

This work was supported by the British Academy [Norse Influence on Early Middle English Prosody].

\section{ORCID}

Nelson Goering (ID) http://orcid.org/0000-0003-2565-3369

\section{References}

Behaghel, Otto \& Burkhard Taeger (eds.). 1996. Heliand und Genesis. 10th edn. Berlin: De Gruyter. Bessinger, J. B. (ed.). 1978. A concordance to The Anglo-Saxon Poetic Records. Ithaca: Cornell University Press.

Bliss, Alan J. 1962. The metre of Beowulf. Oxford: Blackwell.

Braune, Wilhelm. 1994. Althochdeutsches Lesebuch. Ernst Ebbinghaus (ed.). 17th edn. Tübingen: Max Niemeyer Verlag. 
Cable, Thomas M. 1974. The meter and melody of Beowulf. Urbana: University of Illinois Press.

Cable, Thomas M. 1991. The English alliterative tradition. Philadelphia: University of Pennsylvania Press.

Doane, A. N. (ed.). 1991. The Saxon Genesis. Madison: University of Wisconsin Press.

Fulk, R. D. 1992. A history of Old English meter. Philadelphia: University of Pennsylvania Press.

Fulk, R. D., Robert E. Bjork \& John D. Niles (eds.). 2009. Klaeber's Beowulf and the Fight at Finnsburg. 4th edn. Corrected reprint. Toronto: University of Toronto Press.

Goering, Nelson. 2020. Eduard Sievers' Altgermanisch Metrik 125 years on. In Paula RodríguezPuente, Rodrigo Pérez-Lorido \& Carlos Prado-Alonso (eds.), Of ye Olde Englisch langage and textes: New perspectives on Old and Middle English language and literature. Bern: Peter Lang.

Grein, C. W. M. (ed.). 1858. Das Hildebrandslied nach der Handschrift von Neuem herausgegeben, kritisch bearbeitet und erklärt. Göttingen: Georg H. Wigand.

Hofmann, Dietrich. 1991. Die Versstrukturen der altsächsischen Stabreimgedichte Heliand und Genesis. II: Verslisten. Heidelberg: Carl Winter.

Hutcheson, B. R. 1995. Old English poetic metre. Cambridge: D. S. Brewer.

Kendall, Calvin B. 1981. The prefix un- and the metrical grammar of Beowulf. Anglo-Saxon England 10. 39-52.

Krapp, George Philip \& Elliot Van Kirk Dobbie (eds.). 1953. The Anglo-Saxon poetic records: A collective edition. New York: Columbia University Press.

Lachmann, Karl. 1835. Über das Hildebrandslied. In Historisch-philologische Abhandlungen der Königlichen Akademie der Wissenschaften zu Berlin: Aus dem Jahre 1833, 123-162. Berlin: Druckerei der Königlichen Akademie der Wissenschaften.

Lühr, Rosemarie. 1982. Studien zur Sprache des Hildebrandliedes. Frankfurt am Main: Peter Lang.

Mitchell, Bruce, Christopher Ball \& Angus Cameron. 1975. Short titles of Old English texts. AngloSaxon England 4. 207-21.

Momma, Haruko. 1990. Old English ungemete(s): An immeasurably long word? Medieval English Studies Newletter 23. 10-11.

Neidorf, Leonard. 2017. The transmission of Beowulf. Ithaca: Cornell University Press.

Pascual, Rafael J. 2013. Three-position verses and the metrical practice of the Beowulf poet. SELIM 20. 49-79.

Pope, John C. 1966. The rhythm of Beowulf: An interpretation of the normal and hypermetric verseforms in Old English poetry. 2nd edn. New Haven: Yale University Press.

Russom, Geoffrey. 1987. Old English meter and linguistic theory. Cambridge: Cambridge University Press.

Sievers, Eduard (ed.). 1878. Heliand. Halle: Verlag der Buchhandlung des Waisenhauses.

Sievers, Eduard. 1885. Zur rhythmik des germanischen alliterationverses. I. Beiträge zur Geschichte der deutschen Sprache und Literatur 10. 209-314.

Sievers, Eduard. 1893. Altgermanische Metrik. Halle: Max Niemeyer.

Stockwell, Robert P. 1996. Some recent theories of Old English metrics. In Christopher McCully \& J. J. Anderson (eds.), Early English metrics, 73-94. Cambridge: Cambridge University Press.

Suzuki, Seiichi. 1996. The metrical organization of Beowulf: Prototype and isomorphism (Trends in Linguistics: Studies and Monographs 95). Berlin: Mouton de Gruyter.

Suzuki, Seiichi. 2004. The metre of Old Saxon poetry: The remaking of alliterative tradition. Cambridge: D. S. Brewer.

Terasawa, Jun. 1994. Nominal compounds in Old English: A metrical approach (Anglistica 27). Copenhagen: Rosenkilde \& Bagger.

Tiefenbach, Heinrich (ed.). 2010. Altsächsisches Handwörterbuch/A concise Old Saxon dictionary. Berlin: De Gruyter.

Yakovlev, Nicolay. 2008. The development of alliterative metre from Old to Middle English. University of Oxford DPhil diss.https://ora.ox.ac.uk/objects/uuid:02e46bb4-0abb-479d-9c5064be689e013e. 